\title{
Seasonal Uptake of Nutrients by Chenin Blanc in Sand Culture: II. Phosphorus, Potassium, Calcium and Magnesium
}

\author{
W. J. CONRADIE, \\ Oenological and Viticultural Research Institute, Private Bag X5026, Stellenbosch.
}

The author would like to express his appreciation to:

1. Miss D. M. Dwyer for general assistance, preparation of samples and determination of $P$.

2. Miss A. E. Theron for determination of $K, C a$ and $M g$.

\begin{abstract}
The seasonal uptake of phosphorus, potassium, calcium and magnesium as well as their distribution in the vine were determined for Chenin blanc/99R vines grown in sand culture under South African climatic conditions.

Phosphorus absorption showed two distinct peaks-the first ranging from after bud burst until véraison, and the second, less prominent, from about five weeks after harvest into the leaf fall period. Potassium was absorbed from about three weeks after bud burst until four to five weeks after harvest. No potassium was absorbed during leaf fall. Active absorption of calcium started after bud burst and continued until véraison. A second, less pronounced absorption period occurred during the six weeks before leaf fall. Similarly, absorption of magnesium started after bud burst and continued until véraison, after which the absorption rate decreased and ceased with the onset of leaf fall.

A significant amount of the phosphorus and potassium absorbed during the post harvest period was retained in the permanent parts of the vine. However, most of the post harvest calcium and magnesium gains were lost through leaf fall. Most of the calcium retained by the permanent parts of the vine, was stored in the bark.

There was an apparent translocation of potassium from the leaves to the permanent structure of the vine during leaf fall. This was not noticeable for any of the other three nutrients.
\end{abstract}

Over the past 50 years a vast amount of research concerning grape nutrition was done, as reviewed inter alia by Cook (1966) and Champagnol (1978). Nitrogen $(N)$ received most attention, probably because the vine responds more readily to applications of this element. However, the importance of the other four major macroelements, i.e. phosphorus $(P)$, potassium $(K)$, calcium (Ca) and magnesium $(M g)$, for healthy and productive vines cannot be ignored.

Although the vine generally fails to respond to $P$ applications (Winkler et al., 1974) there are indications that response to $N$ is enhanced by the addition of $P$. Bergman et al. (1960) found that $P$ deficiency in sand cultures caused less linear growth and reduced the accumulation of dry material. $P$ is also needed by yeast during must fermentation (Markham \& Byrne, 1967).

$K$ applications resulted in increased grape yields in France (Champagnol, 1978), but this was not as noticeable in California (Winkler et al., 1974). On the other hand, excessive $K$ may negatively influence red wine quality by affecting the $\mathrm{pH}$ (Somers, 1975), and could also induce $M g$ deficiencies (Champagnol, 1978).

Calcium is usually regarded as a soil ameliorant by reducing acidity and improving water penetration in soils of high sodium content (Winkler et al., 1974). Although $\mathrm{Ca}$ deficiencies are rarely observed in vineyards, it is known that $\mathrm{Ca}$ plays an important part in the nutrition of plants (Sprague, 1964). When considering the highly leached soils with low cation exchange capacity which predominate in the coastal regions of South Africa, this element deserves more attention.
$M g$ deficiencies are often encountered in Europe (Delas, 1968; Eggenberger et al., 1975), and is also known in South Africa (Beyers \& Terblanche, 1971). More intensive research into the uptake of this element is, therefore, necessary.

The optimum time for the application of the respective nutrients, especially those susceptible to rapid leaching from the soil, will be strongly affected by their seasonal absorption patterns, i.e. the periods during which the vine shows peak demand for specific elements. As previously reported (Conradie, 1980), seasonal absorption patterns have been determined in many countries but no quantitative data exist for warm countries like South Africa, where very active root growth takes place during the long period between harvest and leaf fall.

In order to establish the seasonal uptake, as well as the distribution of nutrients in vines grown under the climatic conditions of the wine areas of the Western Cape, nutritional studies were carried out in sand culture using the most widely planted scion/rootstock combination, i.e. Chenin blanc/99R, as test plants. This report deals with $P, K, C a$ and $M g$. The general growth and $N$-uptake patterns of vines have been described previously by Conradie $(1980)$.

\section{MATERIALS AND METHODS}

Chenin blanc vines grafted on $99 \mathrm{R}$ and grown in sand culture were used as test plants. Using eight vines for each set of determinations, whole vines were taken 14 
times in the course of their third growing season and were separated into the various organs and analysed. Details concerning the experimental layout, care and sampling of the vines have been described previously (Conradie, 1980).

All samples (excluding grape juice) were prepared for analysis by dry ashing for four hours at $500^{\circ} \mathrm{C}$. Juice was ashed according to the technique of Eschenbruch \& Kleynhans (1974). In all cases the ash was finally dissolved in IN HCL, and the $K, C a$ and $M g$ concentrations were determined by means of atomic absorption spectrophotometry. $P$ was determined by means of the stan- dard OVRI automated colorimetric method. Results were subjected to statistical analyses (Snedecor \& Cochran, 1967) to test the significance of differences in element concentrations between sampling dates.

\section{RESULTS AND DISCUSSION}

Phosphorus: The seasonal uptake and distribution of $P$ in vines are given in Table 1 and summarized in Figure 1. (In this and all subsequent tables "Trunk" includes the rootstock and one to three year old scion wood, i.e. all permanent parts of the vine, excluding roots).

TABLE 1

Seasonal accumulation of $P$ by the various organs of Chenin blanc/99R vines grown in sand culture (mg/vine)

\begin{tabular}{|c|c|c|c|c|c|c|c|c|}
\hline \multirow[b]{2}{*}{ Sampling Date } & \multirow[b]{2}{*}{ Growth Stage } & \multirow[b]{2}{*}{ Trunk $^{1}$} & \multirow[b]{2}{*}{ Roots } & \multirow[b]{2}{*}{ Shoots } & \multirow[b]{2}{*}{ Leaves } & \multirow[b]{2}{*}{ Bunches } & \multicolumn{2}{|c|}{ Total } \\
\hline & & & & & & & Actual & Corrected $^{2}$ \\
\hline 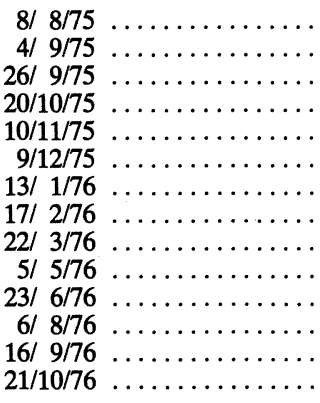 & 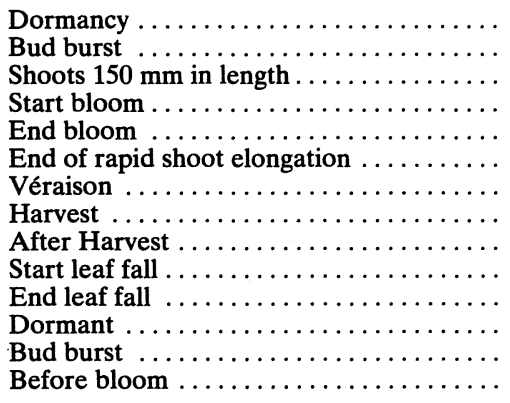 & $\begin{array}{r}94,6 \\
82,4 \\
94,4 \\
99,4 \\
108,2 \\
121,8 \\
106,8 \\
102,0 \\
125,2 \\
134,9 \\
151,7 \\
145,8 \\
162,1 \\
131,6\end{array}$ & $\begin{array}{l}435 \\
435 \\
381 \\
352 \\
349 \\
321 \\
411 \\
361 \\
499 \\
610 \\
621 \\
649 \\
731 \\
667\end{array}$ & $\begin{array}{l}101,4^{3} \\
134,7 \\
229,9 \\
261,1 \\
269,0 \\
260,2 \\
274,7 \\
316,0 \\
274,5 \\
223,1 \\
424^{3}\end{array}$ & $\begin{array}{l}250 \\
412 \\
539 \\
635 \\
514 \\
462 \\
604 \\
745^{4}\end{array}$ & $\begin{array}{r}47 \\
234 \\
512 \\
641\end{array}$ & $\begin{array}{r}530 \\
517 \\
577 \\
835 \\
1145 \\
1477 \\
1933 \\
1878 \\
1362 \\
1665 \\
1048 \\
1019 \\
894 \\
1224\end{array}$ & $\begin{array}{l}2003 \\
2306 \\
2434 \\
2405 \\
2503 \\
2833\end{array}$ \\
\hline $\operatorname{LSD}(5 \%)$ & & 25,2 & 75 & 38,3 & 92 & 81 & 196 & 196 \\
\hline
\end{tabular}

${ }^{1}$ Includes the rootstock.

${ }^{2}$ Where applicable the total has been corrected for amounts of $P$ removed by the crop or lost through leaf fall and pruning.

${ }^{3}$ Leaves and shoots were combined as one sample.

${ }^{4}$ Shed leaves collected during leaf fall.

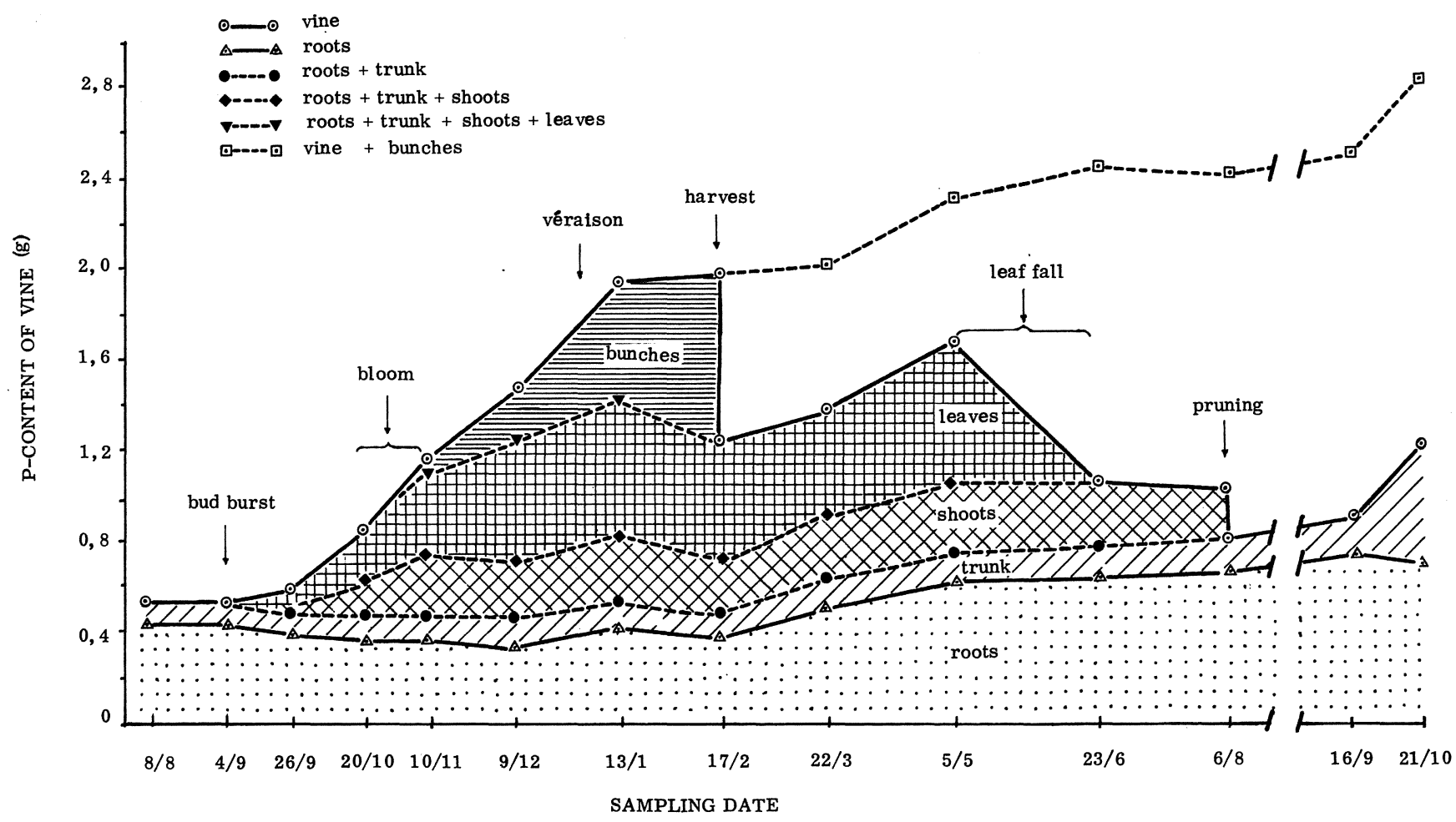

FIG. 1

Seasonal accumulation of phosphorus in a Chenin blanc/99R vine grown in sand culture. 
During the 27 days preceding bud burst no significant change occurred in the total $P$ content of the vine, and the roots contained $82,1 \%$ of the $P$ present in the vine. Active absorption of $P$ appeared to start during the 22 days following bud burst, and the $P$ reserves in the roots played a noticeable role in supplying $P$ to the new shoot growth. During the next 109 days until véraison, $P$ absorption increased rapidly, and the contribution of $P$ reserves from the roots was less noticeable, there was even evidence of $P$ storage in the roots during the 35 days preceding veraison. Although the $P$ content of the vine as a whole remained virtually constant between véraison and harvest, the $P$ content in the bunches increased, seemingly as a result of translocation from the leaves, which showed a loss in $P$ content. At harvest the distribution of $P$ in the vine was as follows: trunk 5,4\%, roots $19,2 \%$, shoots $13,9 \%$, leaves $27,3 \%$ and bunches $34,1 \%$.

During the 33 days following harvest, $P$ absorption resumed, and especially the roots showed large gains. The rate of absorption increased during the 44 days preceding leaf fall. Gains in $P$ were found in the leaves, roots, shoots and trunk. During the period of leaf fall the vines were still gaining $P$, but the leaves now acted as a sink, as was also found for $N$ (Conradie, 1980). This caused a significant decrease in the $P$ content of the shoots. Ultimately, vines lost about $31 \%$ of the $P$ absorbed during the season through leaf fall. No significant changes in $P$ content occurred during dormancy. After pruning at the end of one year, the roots again contained $81,1 \%$ of the $P$ present in the vine, which compares well with the $82,1 \%$ of the previous year. In total, $1875 \mathrm{mg} P$ were absorbed per vine during the growing season, of which $641 \mathrm{mg}$ were removed by the crop, and $266 \mathrm{mg}$ retained by the permanent parts and roots.

Although Fig. 1 also shows two distinct $P$ absorption periods, viz. between budding and véraison, and again from about five weeks after harvest until leaf fall, the post harvest absorption peak was not as pronounced as was found for $N$ by Conradie (1980). Compared to this, Lafon et al. (1965) only found a steady increase in the seasonal $P$ content of the vine, while Hiroyasu (1961) reported a maximum rate of $P$ absorption from May to July. (This probably corresponds with the stage from flowering to véraison.)

Potassium: The seasonal absorption and distribution of $K$ by the vine are given in Table 2 and summarized in Figure 2. Like $P$, the $K$ content of the vine was not affected significantly during the 22 days following bud burst. The significant amount of $K$ accumulated by the new growth seemed to have been mostly supplied by the roots. During the next 74 days until the end of rapid shoot elongation, the rate of $K$ uptake increased significantly and (as in the case of $P$ ) the gain in $K$ by the vine as a whole, was mainly due to the requirements of the new growth, whereas only a small amount of $K$ was stored in the permanent parts of the vine. From this stage until véraison (35 days), the bunches accumulated 2117 mg $K$,-slightly more than the total amount gained by the vine $(2092 \mathrm{mg})$. A slight decrease in $K$ content of the leaves was observed. The vine absorbed $49 \%$ of the yearly requirement of $K$ during the 64 days ranging from the end of bloom to véraison.

During the 35 day period between véraison and harvest the rate of $K$ uptake decreased sharply in spite of the fact that the $K$ content of the bunches was increasing steadily. Eventually, the bunches accumulated $1436 \mathrm{mg} K$, an amount partially supplied by the leaves, shoots and roots. On the other hand, Lévy, et al. (1972) found no translocation of $K$ during the pre-harvest period in vines with a high $K$ content. However, Lafon et al. (1965) also observed appreciable translocations from shoots and leaves. At harvest the grapes contained $66,1 \%$ of the total amount of $K$ in the vine. The remainder was found in the trunk $(4,7 \%)$, roots $(6,9 \%)$, shoots $(11,7 \%)$ and leaves $(10,7 \%)$.

During the 33 days following harvest, sharp and significant increases in the $K$ contents of all organs of the vine occurred, but in contrast to $N$ and $P$, no $K$ was absorbed during the rest of the post harvest period. A relatively small amount of $K(13,6 \%)$ was lost during the leaf fall

TABLE 2

Seasonal accumulation of $K$ by the various organs of Chenin blanc/99R vines grown in sand culture (mg/vine)

\begin{tabular}{|c|c|c|c|c|c|c|c|c|}
\hline \multirow[b]{2}{*}{ Sampling Date } & \multirow[b]{2}{*}{ - Growth Stage } & \multirow[b]{2}{*}{ Trunk $^{1}$} & \multirow[b]{2}{*}{ Roots } & \multirow[b]{2}{*}{ Shoots } & \multirow[b]{2}{*}{ Leaves } & \multirow[b]{2}{*}{ Bunches } & \multicolumn{2}{|c|}{ Total } \\
\hline & & & & & & & Actual & Corrected $^{2}$ \\
\hline 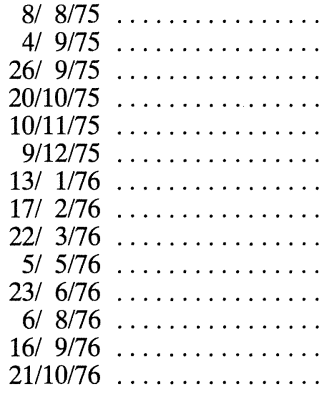 & 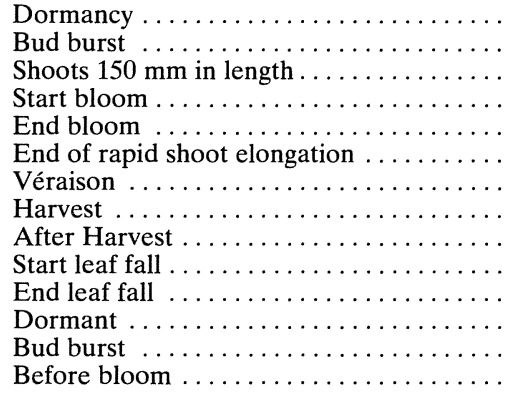 & $\begin{array}{l}274 \\
207 \\
231 \\
303 \\
352 \\
432 \\
393 \\
366 \\
493 \\
451 \\
508 \\
562 \\
564 \\
591\end{array}$ & $\begin{array}{r}791 \\
911 \\
682 \\
666 \\
574 \\
622 \\
709 \\
536 \\
980 \\
899 \\
894 \\
991 \\
1066 \\
1036\end{array}$ & $\begin{array}{rr} & 464^{3} \\
& 707 \\
1 & 034 \\
1 & 062 \\
1 & 056 \\
& 913 \\
1 & 374 \\
1 & 477 \\
1 & 214 \\
1 & 079 \\
1 & \\
1 & 479^{3}\end{array}$ & $\begin{array}{rr} & 655 \\
1 & 007 \\
1 & 278 \\
1 & 210 \\
& 829 \\
1 & 276 \\
1 & 326 \\
1 & 223^{4}\end{array}$ & $\begin{array}{rr} & 238 \\
1 & 594 \\
3 & 711 \\
5 & 147\end{array}$ & $\begin{array}{ll}1 & 065 \\
1 & 117 \\
1 & 377 \\
2 & 332 \\
3 & 205 \\
4 & 988 \\
7 & 080 \\
7 & 791 \\
4 & 124 \\
4 & 152 \\
2 & 616 \\
2 & 632 \\
1 & 630 \\
3 & 107\end{array}$ & $\begin{array}{rr}9 & 271 \\
9 & 299 \\
8 & 986 \\
9 & 002 \\
9 & 079 \\
10 & 556\end{array}$ \\
\hline $\operatorname{LSD}(5 \%)$ & & 73 & 220 & 206 & 208 & 706 & 682 & 682 \\
\hline
\end{tabular}

${ }^{1}$ Includes the rootstock.

${ }^{2}$ Where applicable the total has been corrected for amounts of $K$ removed by the crop or lost through leaf fall and pruning.

${ }^{3}$ Leaves and shoots were combined as one sample.

${ }^{4}$ Shed leaves collected during leaf fall. 


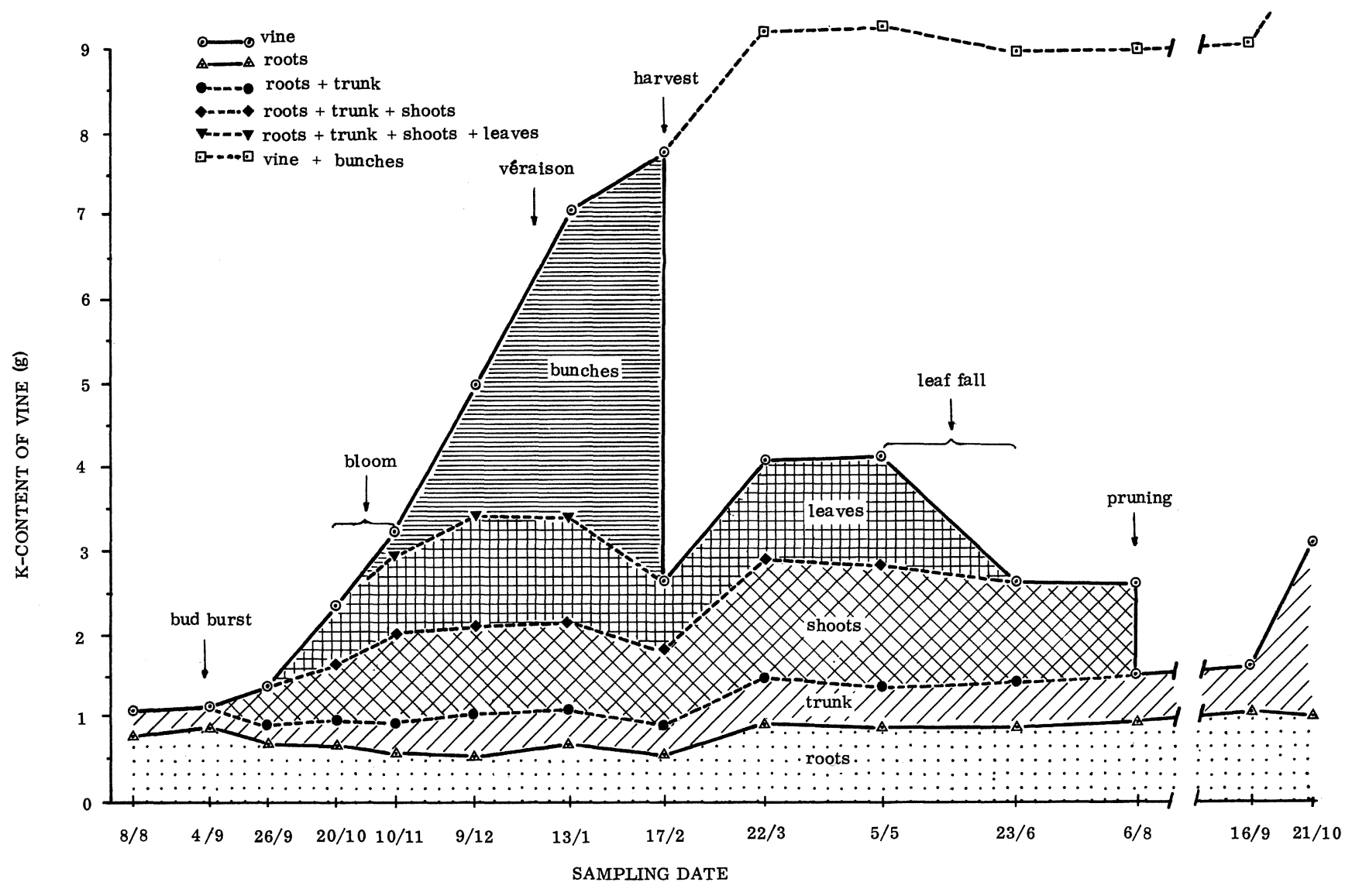

FIG. 2

Seasonal accumulation of potassium in a Chenin blanc/99R vine grown in sand culture.

period. Per vine as a whole $7937 \mathrm{mg} K$ were absorbed during the season, of which $5147 \mathrm{mg}$ were required by the crop and $488 \mathrm{mg}$ were retained in the permanent parts.

The absorption pattern for $K$ (Fig. 2) shows a steady accumulation of this nutrient, except for a decrease in the rate of uptake just before harvest, and the results are comparable with reports of two absorption peaks, one at the start and the other at the end of grape development, respectively (Amirdzanov, 1970).

In an experiment with single node cuttings in sand culture Obbink, Alexander \& Possingham (1973) found that little of the reserve $K$ was utilized during growth. However, in this study with more mature vines, $K$ reserves were used to a large extent.

Calcium: The seasonal uptake and distribution of $\mathrm{Ca}$ by the vine is given in Table 3 and summarized in Figure 3. The bark was found to be an important tissue in this connection, and is, therefore, indicated separately. An insignificant amount of $\mathrm{Ca}$ was absorbed during the 22 days after bud burst. The increase of $C a$ in the new growth was accompanied by a loss in the roots. During this period the $\mathrm{Ca}$-content of the bark doubled, with the result that the bark contained nearly twice as much $\mathrm{Ca}$ as the adjacent woody tissues. During the next 45 days the $\mathrm{Ca}$-content of the vine increased. This was accompanied by a further increase in the $\mathrm{Ca}$-content of the bark, while the roots showed a decrease.

From the end of bloom to véraison $2398 \mathrm{mg} \mathrm{Ca}$ (nearly half of the total for the year) were absorbed. In contrast to $N, P$ and $K$, the bunches required no $\mathrm{Ca}$ between véraison and harvest, and $C a$ was stored mainly in the leaves. The bark on the trunk now contained three times as much $\mathrm{Ca}$ as the woody tissue. At harvest the bunches contained a relatively small part of the $\mathrm{Ca}$ $(7,7 \%)$, whereas the leaves contained the major portion $(46,4 \%)$ and the rest was distributed between the roots $(19,8 \%)$, shoots with accompanying bark $(16,7 \%)$, and the trunk with accompanying bark $(9,4 \%)$.

During the 33 days following harvest changes in total $\mathrm{Ca}$-content were insignificant, but this was followed by a significant increase during the 44 days preceding leaf fall. During the period of active leaf fall, the $C a$ uptake was again insignificant but, as in the case of $N$ and $P$, the $C a$-content of the leaves increased significantly and was accompanied by a significant decrease in the $\mathrm{Ca}$-content of the shoots. As a result of leaf fall the vine lost $54,0 \%$ of its total $\mathrm{Ca}$-content. During the season a vine absorbed $5242 \mathrm{mg} \mathrm{Ca}$, of which $442 \mathrm{mg}$ were removed by the crop. Only $370 \mathrm{mg}$ were stored in the permanent parts, of which $228 \mathrm{mg}$ were found in the bark.

Fig. 3 shows active $\mathrm{Ca}$-absorption about three weeks after bud burst which continued up to véraison. A second less prominent increase occurred during the six weeks before leaf fall. But Hiroyasu (1961) and Lafon et al. (1965) found only gradual accumulation of $\mathrm{Ca}$ from May to September (this would probably correspond with the stage from flowering to harvest). 
TABLE 3

Seasonal accumulation of $\mathrm{Ca}$ by the various organs of Chenin blanc/99R vines grown in sand culture (mg/vine)

\begin{tabular}{|c|c|c|c|c|c|c|c|c|c|c|}
\hline \multirow{2}{*}{ Sampling Date } & \multirow{2}{*}{ Growth Stage } & \multicolumn{2}{|c|}{ Trunk $^{1}$} & \multirow{2}{*}{ Roots } & \multicolumn{2}{|c|}{ Shoots } & \multirow{2}{*}{ Leaves } & \multirow{2}{*}{ Bunches } & \multicolumn{2}{|c|}{ Total } \\
\hline & & Wood & Bark & & Wood & Bark & & & Actual & Corrected $^{2}$ \\
\hline 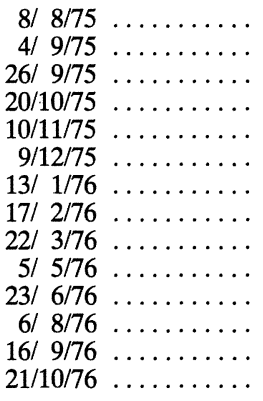 & 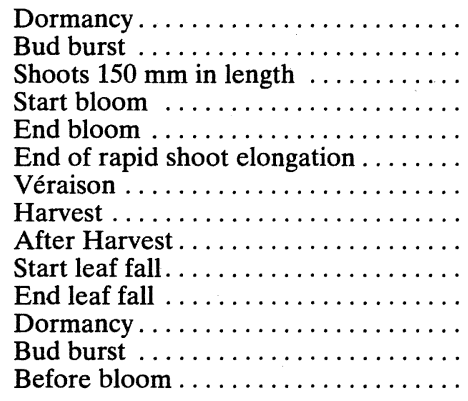 & $\begin{array}{l}243 \\
183 \\
151 \\
130 \\
105 \\
128 \\
128 \\
125 \\
197 \\
243 \\
269 \\
318 \\
233 \\
206\end{array}$ & $\begin{array}{l}118 \\
126 \\
276 \\
269 \\
332 \\
350 \\
385 \\
415 \\
392 \\
343 \\
359 \\
346 \\
447 \\
525\end{array}$ & $\begin{array}{ll}1 & 294 \\
1 & 347 \\
1 & 192 \\
1 & 045 \\
9 & 926 \\
1 & 113 \\
1 & 304 \\
1 & 142 \\
1 & 280 \\
1 & 376 \\
1 & 261 \\
1 & 361 \\
1 & 720 \\
1 & 843\end{array}$ & \begin{tabular}{l|}
\multicolumn{2}{c}{16} \\
135 \\
182 \\
260 \\
357 \\
636 \\
691 \\
705 \\
417 \\
431
\end{tabular} & $\begin{array}{r}8^{3} \\
78 \\
217 \\
276 \\
310 \\
328 \\
364 \\
380 \\
362 \\
349\end{array}$ & $\begin{array}{ll} & 554 \\
1 & 153 \\
1 & 749 \\
2 & 460 \\
2 & 680 \\
2 & 604 \\
2 & 979 \\
3 & 650^{4}\end{array}$ & & $\begin{array}{ll}1 & 655 \\
1 & 655 \\
1 & 786 \\
2 & 212 \\
2 & 981 \\
4 & 158 \\
5 & 379 \\
5 & 769 \\
5 & 527 \\
6 & 025 \\
2 & 668 \\
2 & 805 \\
2 & 400 \\
3 & 323\end{array}$ & $\begin{array}{ll}5 & 969 \\
6 & 467 \\
6 & 760 \\
6 & 897 \\
7 & 272 \\
8 & 195\end{array}$ \\
\hline LSD (5\%) & $\cdots$ & 46 & 74 & 250 & 86 & 41 & 289 & 67 & 476 & 476 \\
\hline
\end{tabular}

${ }^{1}$ Includes the rootstock.

${ }^{2}$ Where applicable the total has been corrected for amounts of $\mathrm{Ca}$ removed by the crop or lost through leaf fall and pruning.

${ }^{3}$ Leaves and shoots were combined as one sample.

${ }^{4}$ Shed leaves collected during leaf fall.

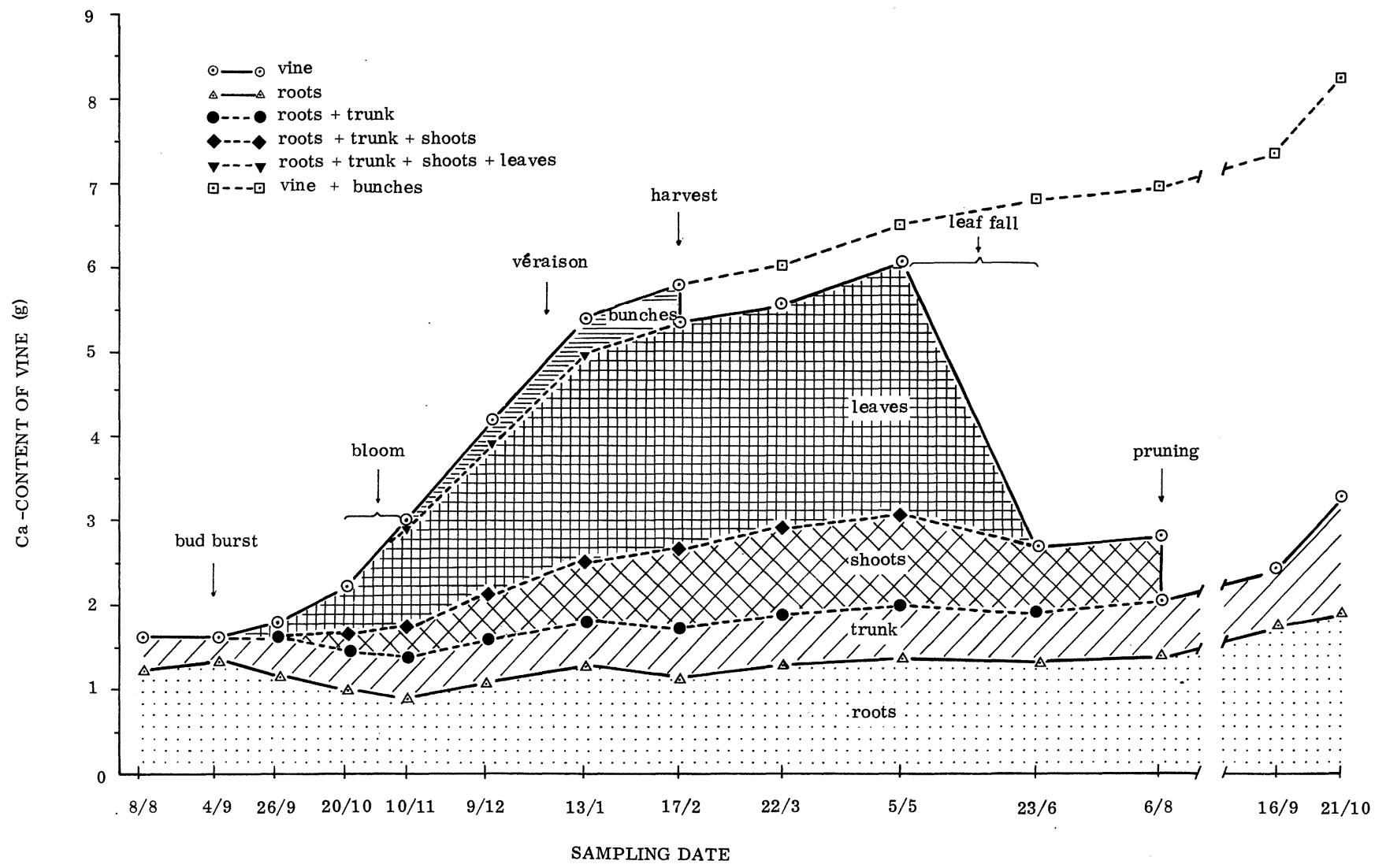

Fig. 3

Seasonal accumulation of calcium in a Chenin blanc/99R vine grown in sand culture.

Magnesium: The seasonal uptake and distribution of $M g$ by the vine is given in Table 4 and summarized in Figure 4.

As for $\mathrm{Ca}$ the contribution of the bark is shown separately. Like the other nutrients, the $M g$-content of the vine did not change significantly during the 27 days before or the 22 days following bud burst. The $M g$ - absorption rate increased during the 45 days until the end of bloom, and a significant $300 \mathrm{mg}$ were absorbed-most of which was required by the new growth, while the roots showed a loss. Unlike $C a$, the $M g$-content of the bark remained relatively constant. From the end of bloom until veraison the rate of absorption increased further, and $43 \%$ of the yearly requirements for $M g$ accumulated. 
TABLE 4

Seasonal accumulation of $M g$ by the various organs of Chenin blanc/99R vines grown in sand culture (mg/vine)

\begin{tabular}{|c|c|c|c|c|c|c|c|c|c|c|}
\hline \multirow{2}{*}{ Sampling Date } & \multirow{2}{*}{ Growth Stage } & \multicolumn{2}{|c|}{ Trunk $^{1}$} & \multirow{2}{*}{ Roots } & \multicolumn{2}{|c|}{ Shoots } & \multirow{2}{*}{ Leaves } & \multirow{2}{*}{ Bunches } & \multicolumn{2}{|c|}{ Total } \\
\hline & & Wood & Bark & & Wood & Bark & & & Actual & Corrected $^{2}$ \\
\hline 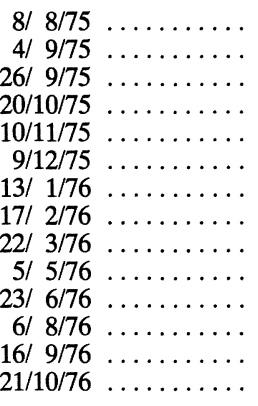 & 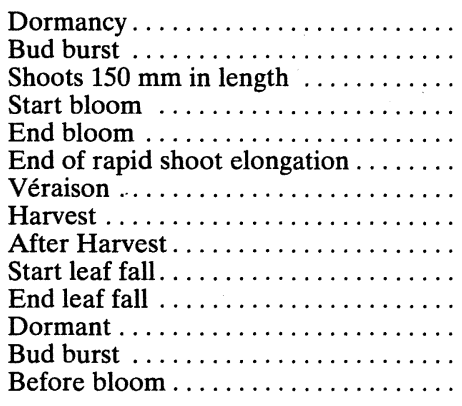 & $\begin{array}{r}62,1 \\
51,9 \\
46,1 \\
46,8 \\
41,8 \\
46,3 \\
48,4 \\
49,0 \\
75,6 \\
56,7 \\
101,0 \\
112,5 \\
93,2 \\
82,6\end{array}$ & $\begin{array}{l}15,8 \\
16,8 \\
33,8 \\
35,4 \\
36,4 \\
42,1 \\
43,9 \\
48,4 \\
51,0 \\
43,0 \\
42,9 \\
42,0 \\
68,5 \\
73,6\end{array}$ & $\begin{array}{l}225 \\
246 \\
216 \\
197 \\
178 \\
195 \\
259 \\
230 \\
317 \\
364 \\
328 \\
343 \\
403 \\
365\end{array}$ & $\begin{array}{r}48 \\
70 \\
102 \\
164 \\
267 \\
311 \\
343 \\
220 \\
180\end{array}$ & $\begin{array}{r}3 \\
27 \\
62 \\
78 \\
95 \\
130 \\
146 \\
150 \\
133 \\
114\end{array}$ & 115 & $\begin{array}{r}23 \\
102 \\
207 \\
234\end{array}$ & $\begin{array}{r}303 \\
314 \\
340 \\
470 \\
640 \\
900 \\
1314 \\
1515 \\
1487 \\
1704 \\
827 \\
792 \\
564 \\
741\end{array}$ & $\begin{array}{ll}1 & 721 \\
1 & 938 \\
1 & 906 \\
1 & 871 \\
1 & 937 \\
2 & 114\end{array}$ \\
\hline $\operatorname{LSD}(5 \%)$ & & 13,8 & 10,1 & 55 & 40 & 31 & 70 & 39 & 116 & 116 \\
\hline
\end{tabular}

${ }^{1}$ Includes the rootstock.

${ }^{2}$ Where applicable the total has been corrected for amounts of $M g$ removed by the crop or lost through leaf fall and pruning.

${ }^{3}$ Leaves and shoots were combined as one sample.

${ }^{4}$ Shed leaves collected during leaf fall.

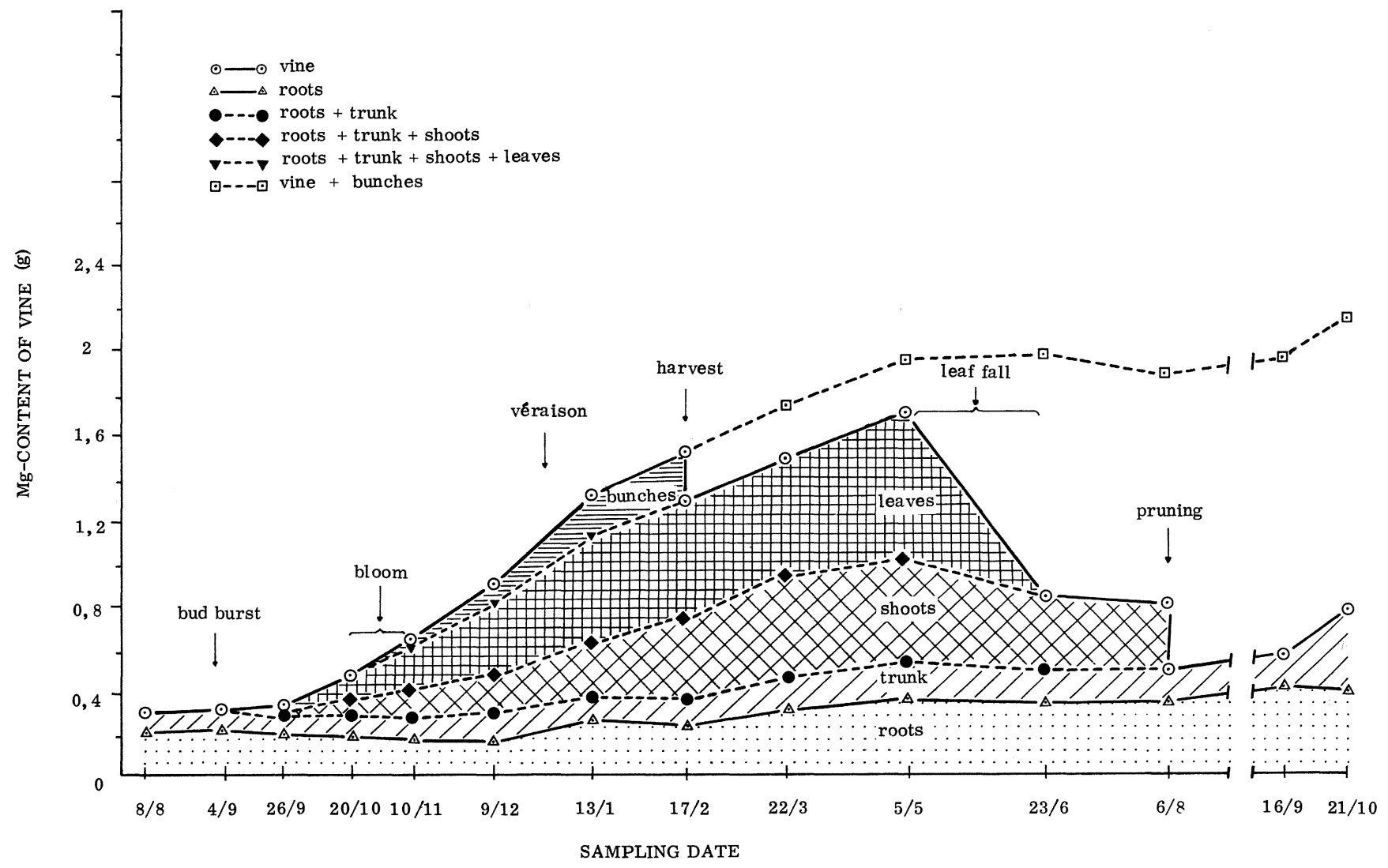

Fig. 4

Seasonal accumulation of magnesium in a Chenin blanc/99R vine grown in sand culture.

The bunches accumulated only $184 \mathrm{mg}$ of the $674 \mathrm{mg}$ gained during this period, resulting in increased $\mathrm{Mg}$ reserves in the roots, shoots and leaves. During the remaining 35 days prior to harvest, a less marked though still significant $M g$ uptake occurred and, as in the case of $\mathrm{Ca}$, the bunches accumulated only a small amount of $\mathrm{Mg}$, the rest being translocated mainly to the shoots and leaves. At harvest the bunches contained $15,4 \%$ of the total amount of $\mathrm{Mg}$, whereas the leaves accounted for the major portion $(36,8 \%)$. The rest of the $M g$ was distributed between the roots $(15,1 \%)$, shoots with corresponding bark $(26,2 \%)$ and trunk with bark $(6,4 \%)$.

During the 33 days immediately following harvest, a significant amount of $M g$ was absorbed. Most of this accumulated in the roots and shoots, and the woody parts of the trunk also showed gains. During the 44 day period 
preceding start of leaf fall, a further significant amount of $M g$ was absorbed. Most of this accumulated in the roots and leaves. During active leaf fall no $M g$ was absorbed, but as in the case of $C a$, the leaves gained a significant amount of $M g$ at the expense of the shoots. Due to leaf fall the vine lost $44,3 \%$ of the total amount of $M g$ absorbed over the season. No significant changes occurred throughout the dormant period. During the season a vine absorbed $1568 \mathrm{mg}$, of which $234 \mathrm{mg}$ were removed by the crop, $195 \mathrm{mg}$ remained in the permanent parts, of which only $26 \mathrm{mg}$ were contained in the bark.

From Fig. 4 it appears as if, in contrast to $N, P, K$ and $\mathrm{Ca}, \mathrm{Mg}$ has only one continuous absorption period. This accords well with the results reported by Hiroyasu (1961) and Lafon et al. (1965).

\section{SUMMARY AND CONCLUSIONS}

Under the conditions of this experiment the absorption patterns of $P$ and $K$ differed appreciably. In both cases active absorption started about three weeks after bud burst, but in the case of $P$, absorption stopped at véraison, while a second peak period occurred from about five weeks after harvest until leaf fall. The same pattern was found for $N$ (Conradie, 1980). $K$ absorption did not stop at harvest, although the rate did slow down, and active absorption continued immediately after harvest. No absorption occurred during leaf fall. The absorption pattern for $M g$ was comparable to that of $K$, in that absorption started at the same time, continued at a fairly even rate and stopped before the onset of leaf fall.

Very active $\mathrm{Ca}$ absorption occurred from after bud burst until véraison, followed by a decreased rate which lasted to the end of leaf fall. During leaf fall $K$ was apparently translocated from the leaves to the permanent parts of the vine. This may be ascribed to the highly mobile nature of the $K$-ion (Salsac, 1977), as none of the other elements showed this phenomenon.

Although the amounts of $P, K, C a$ and $M g$ accumulated during the post harvest period were less than that for $N$ (Conradie, 1980) they still constitute important fractions of the seasonal totals and amounted to $28,1 \%$, $15,3 \%, 21,5 \%$ and $22,6 \%$ for $P, K, C a$ and $M g$ respectively. No new vegetative growth occurred during the post harvest period, and most of the gains in $P$ and $K$ during this period were translocated to the permanent parts, especially the roots. However, with regard to $C a$ and $M g$ Tables 3 and 4 indicate that most of the nutrients absorbed after harvest were lost through leaf fall. For $\mathrm{Ca}$ the post harvest gain was $1128 \mathrm{mg}$, whereas $970 \mathrm{mg}$ $(86,0 \%)$ were lost during leaf fall. (The figure of $970 \mathrm{mg}$ was obtained by subtracting the $C a$ content of the leaves at harvest from that at leaf fall.) Similarly $287 \mathrm{mg}$ $(81,0 \%)$ of the post harvest gain in $M g(354 \mathrm{mg})$ were lost through leaf fall. The bark played an important role as far as $C a$ was concerned, and more than $60 \%$ of the $\mathrm{Ca}$ gained by the permanent parts was contained in the bark. This was to be expected (Greulach, 1973) and points to the immobility of $\mathrm{Ca}$ (most of the $\mathrm{Ca}$ was probably in insoluble form).

Under the local climatic conditions the post harvest period has thus proved to be of great importance for the accumulation of reserves of $P$ and $K$ but of less significance in the case of $C a$ and $M g$.

\section{LITERATURE CITED}

AMIRDZANOV, A. G., 1970. Assimilation of $N, P$ and $K$ by vines during the growing season. Fiziol Biohim. Kultur Rast. 2, 533-539 (Abstr.: Hort. Abstr. 41, 8660, 1971).

BERGMAN, E. L., KENWORTHY, A. L., BASS, S. T. \& BENNE, E. J., 1960. Growth of Concord grapes in sand cultures as related to various levels of essential nutrient elements. Proc. Am. Soc. hort. Sci. 75, 329-340.

BEYERS, E. \& TERBLANCHE, J. H., 1971. Identification and control of trace element deficiencies. VI. Magnesium deficiency. Decid. Fruit Grow. 21, 305-309.

CHAMPAGNOL, F., 1978. Fertilisation optimale de la vigne. Progrès agric. Vitic. 95, 432-440.

CONRADIE, W. J., 1980. Seasonal uptake of nutrients by Chenin blanc in sand culture. I. Nitrogen. S. Afr. J. Enol. Vitic. 1, 59-65.

COOK, J. A., 1966. Grape Nutrition. In: Childers, N. F. (Ed.): Fruit Nutrition, 777-812. Horticultural Publications, New Jersey.

DELAS, J., 1968. A study by foliar analyses of magnesium deficiency in vines of the Bordeaux region. Mem. gen. II Coloq. eur. medit. Contr. Fert. Plant cult. Seville 343-350 (Abstr.: Hort. Abstr. 41, 6246, 1971).

EGGENBERGER, W., KOBLET, W., MISCHLER, M., SCHWARZENBACH, H. \& SIMON J., 1975. Weinbau, Chapter 2, Verlag Huber \& Co., Frauenfeld.

ESCHENBRUCH, R. \& KLEYNHANS, P. H., 1974. The influence of copper-containing fungicides on the copper content of grape juice and on hydrogen sulphide formation. Vitis 12, 320-324.

GREULACH, V. A., 1973. Plant Function and Structure, Chapter 6. The Macmillan company, New York.

HIROYASU, T., 1961. Nutritional and physiological studies on the grapevine. J. Jap. Soc. Hort. Sci. 30, 111-116 (Abstr.: Hort. Abstr. 32, 2677, 1962).

LAFON, J., COUILLAUD, P., GAY-BELLILE, F. \& LÉVY, J. F., 1965. Rythme de l'absorption minérale de la vigne au cours d'un cycle végétatif. Vignes Vins 140, 17-21.

LÉVY, J. F., CHALER, G., CAMHAJI, E. \& HÉGO, C., 1972. Neue statistische Untersuchungen über die Zusammenhänge zwischen dem Mineralstoffgehalt der Blätter und den Ernährungsbedingungen der Rebe. Vignes Vins 212, 21-25.

MARKHAM, E. \& BYRNE, W. J., 1967. Uptake, storage and utilization of phosphate by yeast. II. Limiting factors of yeast uptake. J. Inst. Brew. 73, 271-273.

OBBINK, J. G., ALEXANDER, D. McE. \& POSSINGHAM, J. V., 1973. Use of nitrogen and potassium reserves during growth of grape vine cuttings. Vitis 12, 207-213.

SALSAC, L., 1977. Le Potassium dans le vegetal: Localisation cytologique, absorption et transport, role physiologique. Au Service de L' Agriculture. Colloque sur le Potassium dans ses rapports avec la Vigne et la Vin. Montpellier, $1-11$.

SNEDECOR, G. W. \& COCHRAN, W. G., 1967. Statistical methods, Sixth Edition. The Iowa State University Press, Iowa.

SOMERS, T. C., 1975. In search of quality for red wines. Food Tech. in Aust. 27, 49-56.

SPRAGUE, H. B., 1964. Why do plants starve? In: Sprague, H. B. (Ed.): Hunger signs in crops, 1-23. David McKay Co., New York.

WINKLER, A. J., COOK, J. A., KLIEWER, W. M. \& LIDER, L. A., 1974. General Viticulture, Chapter 17. University of California Press, Berkeley. 